\title{
Analysis of Indonesian Naval Ship Maintenance Strategy at Jakarta Military Sea Lift Unit to Support Sea Transportation
}

\author{
Mei Edi Prayitno ${ }^{1}$, Aries Sudiarso ${ }^{2}$, Dohar Sianturi ${ }^{3}$ \\ (Received: 30 December 2021 / Revised: 30 December 2021 / Accepted: 31 December 2021)
}

\begin{abstract}
Jakarta Military Sea Lift Unit caused by the age of most of the ships more than 20 years. The purpose of the study was to analyze the strategy of maintaining ship readiness through system maintenance activities. The research method is quantitative with a survey approach with an analysis model based on Strength, Weakness, Opportunity, and Threat (SWOT). Research respondents are purposive sampling that have relevance in the field of ship maintenance. The results showed that to improve ship readiness through maintenance systems, was carried out by increasing the capabilities of human resources, Management Planned maintenance systems, The availability of spare parts, and the capability of the Ship Maintenance Facility Unit. The improvement of personnel capabilities and skills is carried out through training activities in collaboration with the original engine manufacturer (OEM). This ship maintenance system is based on a planned maintenance system supported by the availability of spare parts and the capability of Ship Maintenance Facility Units. Contribution of the research to maintain the readiness of ships to support operational activities, which has implications for the readiness and sustainability.
\end{abstract}

Keywords $\longrightarrow$ hip maintenance system, spare part, ship readiness.

\section{INTRODUCTION}

A long with the increasing security conflict in the Southeast Asia region as a result of the dispute over the South China Sea (SCS) area which causes territorial violations and violations of the theft of natural fishery resources in the North Natuna Sea. The impact of the increasing SCS dispute, the Chinese state has developed a defense policy by building a military base in the waters in the SCS, as a front base to maintain the stability of the waters which is claimed unilaterally. This policy of the Chinese state has had an impact on the presence of the naval forces of foreign countries such as the United States [1]. In terms of military strength, China can realize military power as a way to increase the country's existence among regional countries. On the economic aspect, the Chinese state has issued a national policy by formulating a One Belt One Road (OBOR) strategy to obtain fast raw materials and facilitate the marketing of industrial products [2]. The existence of disputes in the SCS area and the Chinese state's action to build military bases in the Spratly Islands have increased conflicts that have an impact on the security of Indonesia's border waters in the SCS, so the Indonesian Navy needs to increase the readiness of defense equipment to safeguard national interests.

Mei Edi Prayitno is with Study Program of Marine Defense Strategy, Indonesian Defense University, Bogor, 16810, Indonesia. E-mail: meiediprayitno@gmail.com

Aries Sudiarso is with Study Program of Marine Defense Strategy, Indonesian Defense University, Bogor, 16810, Indonesia. E-mail: aries25st@yahoo.co.id

Dohar Sianturi is with Study Program of Marine Defense Strategy, Indonesian Defense University, Bogor, 16810, Indonesia. E-mail: unhan@idu.ac.id
The preparation of Indonesian Navy ships to support military sea transportation activities for shifting troops, materials and logistics need to be prepared in order to have the endurance ability and sustainability. Strategic steps to increase the ship readiness to support marine transportation activities are carried out during the elements of the Indonesian Navy ships before they are used and during operational activities.

The readiness of the Indonesian Navy's ship is currently at a condition that is not yet maximized, so steps are needed to increase the ability to be present in border waters including the SCS to maintain national interests at sea to support the shift of troops, materials, and logistics as sea transportation through military marine activities. Increasing the readiness of Navy ships, especially under the ranks of the Jakarta Military Sea Lift unit, various strategic steps are needed, including the development of human resource capabilities (HR) for the Ships crew, platform readiness consisting of shipbuilding, safety equipment, and ship machinery, sensor weapon and command (Sewaco) as well, that consisting of weapons systems, communications, and navigation, logistical support in the aspect of fuel oil, base facilities in this case land power capacity and ship maintenance facilities support capabilities [3]. Jakarta Military Sea Lift Unit is one of the Indonesia Navy institution that has the task-of shifting troops, materials, and logistics to the area of operation. In general, warships are prepared to operate for 30 years. To maintain the readiness of the Indonesian Navy ships, an adequate maintenance system is needed [4].

This study is to analyze the capability of the Navy's ship maintenance system at the Jakarta Military Sea Lift Unit to support sea transportation and determine a strategy for the ship maintenance system based on Strength, Weakness, Opportunity, and Threat (SWOT) to support the shift of troops, materials and logistics to the operational area to support military operations for war 
(MOW) and military operations other than war (MOTW).

\section{METHOD}

The approach used in this research is a quantitative approach. The quantitative approach is used because of the formulation of symptoms, information and information in increasing the warship readiness of the Jakarta Military Sea Lift Unit to support sea transportation. Quantitative research is based on data from variables measured by numbers for later analysis in accordance with applicable statistical procedures [5]. In quantitative research, it aims to develop a mathematical model, where this research does not only use theories taken from literature or theory studies, but it is also very important to build hypotheses that are related to the phenomenon to be studied. [5]. The characteristics of quantitative research are carried out to analyze specific problems that are used as the focus of research. This quantitative study was conducted to analyze the readiness of the Jakarta Military Sea Lift Unit warship to support military sea transportation through the identification of research variables.
The maintenance budget as part of the defense budget expenditure is needed for equipment

\section{A. Strategy Based on Strength, Weakness, Opportunity and Threat (SWOT).}

SWOT analysis is a strategic planning instrument used to evaluate the Strengths, Weaknesses, Opportunities, and Threats (SWOT) contained in an activity to achieve goals. Strengths are internal factors that support the organization in achieving its goals. Weaknesses are internal factors that hinder the organization in achieving its goals. Opportunities are external factors that support the organization in achieving its goals. Threats (threats) are external factors that hinder the organization in achieving its goals. The SWOT matrix is a tool for compiling the organization's strategic factors that can clearly describe the external opportunities and threats facing the organization and can be adjusted to the strengths and weaknesses, Table 1. By SWOT analysis, it is possible to identify performance in the Navy's ship maintenance system [6].

TABLE 1.

INTERNAL AND EXTERNAL MATRIX FACTORS

\begin{tabular}{|l|c|c|}
\hline $\begin{array}{c}\text { External Factor } \\
\text { Evaluation }\end{array}$ & $\begin{array}{c}\text { Internal Factor } \\
\text { Evaluation }\end{array}$ & Strengths (S) \\
\hline Opportunities (O) & $\begin{array}{c}\text { Strategy (S-O) } \\
\text { The strategy is determined by utilizing all } \\
\text { strengths to seize and take full advantage of } \\
\text { opportunities }\end{array}$ & $\begin{array}{c}\text { Strategy (O-W) } \\
\text { Strategies that are implemented by taking } \\
\text { advantage of existing opportunities by } \\
\text { minimizing existing weaknesses }\end{array}$ \\
\hline Threats (T) & $\begin{array}{c}\text { Strategy (S-T) } \\
\text { A strategy that is implemented by utilizing } \\
\text { all the strengths it has to overcome } \\
\text { threat }\end{array}$ & $\begin{array}{c}\text { Strategy (T-W) } \\
\text { A strategy that is implemented based on } \\
\text { activities that are defensive in nature and try } \\
\text { to minimize weaknesses and avoid threats }\end{array}$ \\
\hline
\end{tabular}

\section{B. Determination of Research Sampling}

The determination of the research sample was prepared using a purposive sampling model in detail using certain considerations and objectives in accordance with the objectives of this study [5]. Purposive sampling is a sample of respondents who have the capacity and understanding with the topic of increasing the warship readiness of the Jakarta Military Sea Lift Unit. The criteria for purposive sampling include: (1) having knowledge of the readiness of the Indonesian Navy ships, (2) personnel who have a direct relationship with the Navy ship maintenance system, (2) having a working period of more than 5 years in preparing of the Navy ships readiness.

\section{Object Research}

To improve the ship maintenance system at the Jakarta Military Sea Lift Unit, there will be an analysis of the Crew on the Navy's ships, human resources for ship maintenance facilities, spare parts, planned maintenance systems, and Ship Maintenance Facility Unit to support the Navy's ship maintenance strategy to improve readiness. Indonesian Navy ships in shifting troops, materials and logistics to the area of operation. modernization and adequate maintenance to increase ship readiness, a planned maintenance system is needed [7].

\section{RESULTS AND DISCUSSION}

Analyzing the TNI AL ship maintenance strategy in detail at the Jakarta Military Sea Lift Unit by involving all elements and personnel involved in the ship maintenance system. The results of the questionnaire assessment using SWOT analysis showed that of the 9 respondents who had been given an assessment, all of them met the requirements. From the results of the weighting and ranking assessment with strategic objectives to support the improvement of the Indonesian Navy ships in the Jakarta Military Sea Lift Unit, (Tabel 2, Tabel 3, Tabel 4, and Table 5), it is known that the following results:

1. The results of the SWOT assessment for the internal Strength factor with a value of 42.35 .

2. The results of the SWOT assessment for the internal factor Weakness with a value of 32.77.

3. The results of the SWOT assessment for external factors Opportunity with a value of 31.65

4. The results of the SWOT assessment for external factors Threats (Threats) with a value of 29.90. 
International Journal of Marine Engineering Innovation and Research, Vol. 6(4), Dec. 2021. 267-276

TABEL 2.

SWOT ASSESSMENT RESULTS OF INTERNAL FACTORS (STRENGTH-S)

\begin{tabular}{|c|c|c|c|c|c|c|c|c|c|c|c|c|c|c|c|c|c|c|c|c|c|}
\hline \multirow[t]{3}{*}{ No } & \multirow[t]{3}{*}{ Question } & \multirow[t]{3}{*}{$\begin{array}{l}\text { Weight } \\
\text { Factor }\end{array}$} & \multicolumn{9}{|c|}{$\begin{array}{l}\text { Weight (1= Slightly important; } \\
\text { 2=Somewhat important, } \\
\text { 3=Important; } 4 \text { =Very } \\
\text { important) }\end{array}$} & \multicolumn{9}{|c|}{$\begin{array}{l}\text { Rating (1=Very Low Influence; } \\
\text { 2=Low Influence; 3=Medium } \\
\text { Influence; 4=High Influence; } \\
\text { 5=Very High Influence) }\end{array}$} & \multirow[t]{3}{*}{ Total } \\
\hline & & & \multicolumn{9}{|c|}{ Respondent } & \multicolumn{9}{|c|}{ Respondent } & \\
\hline & & & 1 & 2 & 3 & 4 & 5 & 6 & 7 & 8 & 9 & 1 & 2 & 3 & 4 & 5 & 6 & 7 & 8 & 9 & \\
\hline \multicolumn{22}{|c|}{ Internal Factors - Strength (S) } \\
\hline 1 & $\begin{array}{l}\text { Availability of the system } \\
\text { maintenance manual guidance }\end{array}$ & 0.05 & 4 & 3 & 4 & 3 & 4 & 3 & 3 & 3 & 3 & 4 & 2 & 4 & 4 & 2 & 4 & 2 & 3 & 2 & 4.55 \\
\hline 2 & $\begin{array}{l}\text { The organization of the Navy's } \\
\text { ship maintenance system }\end{array}$ & 0.05 & 4 & 3 & 4 & 3 & 4 & 3 & 3 & 3 & 4 & 5 & 2 & 2 & 5 & 2 & 5 & 2 & 5 & 2 & 5.05 \\
\hline 3 & Naval ship maintenance facilities & 0.10 & 2 & 3 & 2 & 3 & 2 & 3 & 2 & 3 & 2 & 3 & 1 & 3 & 3 & 1 & 3 & 1 & 3 & 2 & 5.00 \\
\hline 4 & $\begin{array}{l}\text { Compiled a network of Navy's } \\
\text { ship maintenance systems }\end{array}$ & 0.10 & 3 & 3 & 3 & 3 & 3 & 3 & 3 & 3 & 3 & 4 & 3 & 4 & 4 & 3 & 4 & 3 & 3 & 3 & 9,30 \\
\hline 5 & $\begin{array}{l}\text { The policy for the development of } \\
\text { the Indonesian Navy's ship } \\
\text { strength program is in accordance } \\
\text { with the Minimum Essential } \\
\text { Force 2020-2024 }\end{array}$ & 0.15 & 3 & 3 & 3 & 3 & 3 & 3 & 3 & 3 & 3 & 4 & 3 & 4 & 4 & 3 & 4 & 3 & 4 & 3 & 14.40 \\
\hline 6 & Inventory system & 0.05 & 3 & 3 & 3 & 3 & 3 & 3 & 3 & 3 & 3 & 3 & 3 & 3 & 3 & 3 & 3 & 3 & 3 & 3 & 4.05 \\
\hline \multicolumn{2}{|r|}{ Total } & 0.50 & & & & & & & & & & & & & & & & & & & 42.35 \\
\hline
\end{tabular}

TABEL 3.

SWOT ASSESSMENT RESULTS OF INTERNAL FACTORS (STRENGTH-S)

\begin{tabular}{|c|c|c|c|c|c|c|c|c|c|c|c|c|c|c|c|c|c|c|c|c|c|}
\hline \multirow{3}{*}{ No } & \multirow{3}{*}{ Question } & \multirow{3}{*}{$\begin{array}{l}\text { Weight } \\
\text { Factor }\end{array}$} & \multicolumn{9}{|c|}{$\begin{array}{c}\text { Weight (1= Slightly important; } \\
\text { 2=Somewhat important, } \\
\text { 3=Important; } 4 \text { =Very } \\
\text { important) }\end{array}$} & \multicolumn{9}{|c|}{$\begin{array}{l}\text { Rating (1=Very Low Influence; } \\
\text { 2=Low Influence; 3=Medium } \\
\text { Influence; 4=High Influence; } \\
\text { 5=Very High Influence) }\end{array}$} & \multirow{3}{*}{ Total } \\
\hline & & & \multicolumn{9}{|c|}{ Respondent } & \multicolumn{9}{|c|}{ Respondent } & \\
\hline & & & 1 & 2 & 3 & 4 & 5 & 6 & 7 & 8 & 9 & 1 & 2 & 3 & 4 & 5 & 6 & 7 & 8 & 9 & \\
\hline \multicolumn{22}{|c|}{ Internal Factors - Weakness (W) } \\
\hline 1 & $\begin{array}{l}\text { Limited occupancy of the ship } \\
\text { crew at the Jakarta Military Sea } \\
\text { Lift Unit }\end{array}$ & 0.03 & 3 & 4 & 3 & 3 & 4 & 3 & 3 & 3 & 4 & 3 & 2 & 3 & 2 & 2 & 2 & 2 & 2 & 2 & 1.98 \\
\hline 2 & $\begin{array}{l}\text { Low maintenance ability of ships } \\
\text { Crew }\end{array}$ & 0.04 & 3 & 3 & 3 & 3 & 3 & 3 & 3 & 3 & 3 & 4 & 2 & 2 & 3 & 2 & 2 & 2 & 2 & 2 & 2.52 \\
\hline 3 & $\begin{array}{l}\text { Limited readiness of the ships } \\
\text { platform of the Jakarta Military } \\
\text { Sea Lift Unit }\end{array}$ & 0.05 & 3 & 3 & 2 & 3 & 3 & 3 & 3 & 3 & 3 & 2 & 2 & 2 & 4 & 2 & 3 & 2 & 3 & 2 & 3.20 \\
\hline 4 & $\begin{array}{l}\text { Limited readiness of ship Sewaco } \\
\text { at the Jakarta Military Sea Lift } \\
\text { Unit }\end{array}$ & 0.05 & 3 & 3 & 3 & 3 & 3 & 3 & 3 & 3 & 3 & 4 & 2 & 2 & 3 & 2 & 4 & 2 & 4 & 2 & 3.75 \\
\hline 5 & $\begin{array}{l}\text { Operating fuel support less than } \\
80 \text { percent }\end{array}$ & 0.05 & 3 & 3 & 3 & 3 & 3 & 3 & 3 & 3 & 3 & 2 & 3 & 4 & 3 & 3 & 4 & 3 & 3 & 3 & 4.20 \\
\hline 6 & $\begin{array}{l}\text { Limited electrical power capacity } \\
\text { in Naval base }\end{array}$ & 0.02 & 3 & 3 & 3 & 3 & 3 & 3 & 3 & 3 & 3 & 2 & 3 & 3 & 2 & 3 & 3 & 3 & 3 & 3 & 1.50 \\
\hline 7 & $\begin{array}{l}\text { Low personnel capability of the } \\
\text { Ship Maintenance Facility Unit }\end{array}$ & 0.05 & 3 & 3 & 2 & 3 & 3 & 3 & 3 & 3 & 3 & 3 & 2 & 2 & 2 & 2 & 3 & 2 & 3 & 2 & 3.05 \\
\hline 8 & $\begin{array}{l}\text { Organizational personnel } \\
\text { occupancy of ship maintenance } \\
\text { facilities is less than } 80 \text { percent }\end{array}$ & 0.03 & 3 & 3 & 3 & 3 & 3 & 3 & 3 & 3 & 3 & 2 & 3 & 3 & 1 & 3 & 2 & 3 & 2 & 3 & 1.98 \\
\hline 9 & $\begin{array}{l}\text { Decreasing the ability of the } \\
\text { facilities of Ship Maintenance } \\
\text { Facilities Unit }\end{array}$ & 0.03 & 3 & 3 & 3 & 3 & 3 & 3 & 3 & 3 & 3 & 4 & 3 & 2 & 2 & 1 & 2 & 1 & 2 & 2 & 1.71 \\
\hline 10 & $\begin{array}{l}\text { Limited equipment facilities of } \\
\text { Ship Maintenance Facility Unit }\end{array}$ & 0.03 & 3 & 2 & 2 & 3 & 2 & 3 & 2 & 3 & 2 & 4 & 2 & 2 & 2 & 2 & 3 & 2 & 3 & 2 & 1.68 \\
\hline 11 & Limited availability of spare parts & 0.02 & 3 & 3 & 3 & 3 & 3 & 3 & 3 & 3 & 3 & 4 & 2 & 1 & 3 & 1 & 1 & 4 & 1 & 4 & 1.26 \\
\hline 12 & $\begin{array}{l}\text { The dynamics of the Navy's ship } \\
\text { operations are very high }\end{array}$ & 0.03 & 3 & 3 & 3 & 3 & 3 & 3 & 3 & 3 & 3 & 3 & 1 & 2 & 1 & 3 & 2 & 1 & 2 & 1 & 1.44 \\
\hline 13 & $\begin{array}{l}\text { Several Indonesian Navy ships do } \\
\text { not yet have data on software } \\
\text { planned maintenance system and } \\
\text { spare part list }\end{array}$ & 0.02 & 4 & 3 & 4 & 4 & 3 & 4 & 3 & 4 & 3 & 2 & 2 & 1 & 2 & 2 & 4 & 2 & 4 & 2 & 1.52 \\
\hline 14 & $\begin{array}{l}\text { The ship maintenance system is } \\
\text { still conventional }\end{array}$ & 0.05 & 3 & 2 & 2 & 3 & 2 & 3 & 2 & 3 & 2 & 3 & 2 & 2 & 2 & 2 & 4 & 2 & 4 & 2 & 2.95 \\
\hline & Total & 0.50 & & & & & & & & & & & & & & & & & & & 32.77 \\
\hline
\end{tabular}


TABEL 4.

SWOT ASSESSMENT RESULTS OF EXTERNAL FACTORS - OPPORTUNITY (O)

\begin{tabular}{|c|c|c|c|c|c|c|c|c|c|c|c|c|c|c|c|c|c|c|c|c|c|}
\hline \multirow[t]{3}{*}{ No } & \multirow[t]{3}{*}{ Question } & \multirow[t]{3}{*}{$\begin{array}{l}\text { Weight } \\
\text { Factor }\end{array}$} & \multirow{2}{*}{\multicolumn{9}{|c|}{$\begin{array}{c}\text { Weight (1= Slightly important; } \\
\text { 2=Somewhat important, } \\
\text { 3=Important; } 4 \text { =Very } \\
\text { important) }\end{array}$}} & \multicolumn{9}{|c|}{$\begin{array}{l}\text { Rating (1=Very Low Influence; } \\
\text { 2=Low Influence; 3=Medium } \\
\text { Influence; 4=High Influence; } \\
\text { 5=Very High Influence) }\end{array}$} & \multirow[t]{3}{*}{ Total } \\
\hline & & & \multicolumn{6}{|c|}{ Respondent } & & & & \multicolumn{9}{|c|}{ Respondent } & \\
\hline & & & 1 & 2 & 3 & 4 & 5 & 6 & 7 & 8 & 9 & 1 & 2 & 3 & 4 & 5 & 6 & 7 & 8 & 9 & \\
\hline \multicolumn{22}{|c|}{ External Factors - Opportunity (O) } \\
\hline 1 & Cooperation with the shipyard & 0.05 & 2 & 3 & 3 & 2 & 3 & 2 & 3 & 2 & 3 & 2 & 1 & 2 & 2 & 1 & 2 & 2 & 2 & 2 & 8.00 \\
\hline 2 & $\begin{array}{l}\text { Cooperation with supporting } \\
\text { industries }\end{array}$ & 0.05 & 3 & 3 & 2 & 3 & 3 & 3 & 3 & 3 & 3 & 3 & 1 & 2 & 3 & 1 & 2 & 2 & 2 & 2 & 2.60 \\
\hline 3 & $\begin{array}{l}\text { Cooperation with domestic } \\
\text { suppliers }\end{array}$ & 0.10 & 4 & 3 & 3 & 4 & 3 & 3 & 3 & 4 & 3 & 4 & 3 & 3 & 4 & 3 & 3 & 3 & 3 & 3 & 9.80 \\
\hline 4 & $\begin{array}{l}\text { Cooperation with domestic } \\
\text { Original Engine Manufacturers } \\
\text { (OEMs) }\end{array}$ & 0.10 & 3 & 3 & 3 & 3 & 3 & 3 & 3 & 3 & 3 & 4 & 3 & 2 & 4 & 3 & 2 & 2 & 2 & 2 & 7.20 \\
\hline 5 & $\begin{array}{l}\text { Advances in information } \\
\text { technology based on } 4.0\end{array}$ & 0.15 & 3 & 3 & 3 & 3 & 3 & 3 & 3 & 3 & 3 & 3 & 3 & 3 & 3 & 3 & 3 & 3 & 3 & 3 & 4.05 \\
\hline & Total & 0.50 & & & & & & & & & & & & & & & & & & & 31.65 \\
\hline
\end{tabular}

TABEL 5.

SWOT ASSESSMENT RESULTS OF EXTERNAL FACTORS - THREAT (T)

\begin{tabular}{|c|c|c|c|c|c|c|c|c|c|c|c|c|c|c|c|c|c|c|c|c|c|}
\hline \multirow[t]{3}{*}{ No } & \multirow[t]{3}{*}{ Question } & \multirow[t]{3}{*}{$\begin{array}{l}\text { Weight } \\
\text { Factor }\end{array}$} & \multicolumn{9}{|c|}{$\begin{array}{c}\text { Weight (1= Slightly important; } \\
\text { 2=Somewhat important, } \\
\text { 3=Important; } 4 \text { =Very } \\
\text { important })\end{array}$} & \multicolumn{9}{|c|}{$\begin{array}{c}\text { Rating (1=Very Low Influence; } \\
\text { 2=Low Influence; 3=Medium } \\
\text { Influence; 4=High Influence; } \\
\text { 5=Very High Influence) }\end{array}$} & \multirow[t]{3}{*}{ Total } \\
\hline & & & \multicolumn{9}{|c|}{ Respondent } & \multicolumn{9}{|c|}{ Respondent } & \\
\hline & & & 1 & 2 & 3 & 4 & 5 & 6 & 7 & 8 & 9 & 1 & 2 & 3 & 4 & 5 & 6 & 7 & & & \\
\hline \multicolumn{22}{|c|}{ External Factors - Threat (T) } \\
\hline 1 & $\begin{array}{l}\text { Embargo on spare parts from } \\
\text { overseas suppliers }\end{array}$ & 0.05 & 2 & 2 & 2 & 2 & 2 & 2 & 2 & 2 & 2 & 1 & 4 & 3 & 1 & 4 & 1 & 4 & & & 6.90 \\
\hline 2 & Depends on experts from abroad & 0.05 & 2 & 3 & 2 & 3 & 3 & 3 & 3 & 3 & 3 & 2 & 3 & 4 & 2 & 3 & 2 & 3 & & & 16.50 \\
\hline 3 & $\begin{array}{l}\text { There has been no cooperation } \\
\text { with overseas Original Engine } \\
\text { Manufacturers }\end{array}$ & 0.10 & 2 & 3 & 3 & 3 & 3 & 3 & 3 & 3 & 3 & 1 & 4 & 2 & 1 & 4 & 1 & 4 & & & 6.50 \\
\hline & Total & 0.50 & & & & & & & & & & & & & & & & & & & 29.90 \\
\hline
\end{tabular}

From the results of the assessment of the Strengths, Weaknesses, Opportunities, and Threats (SWOT) contained in an activity to achieve goals, it can be described in four quadrants [8].

a. Quadrant I. An organization has strengths and opportunities so that it can direct the entire internal potential of the organization to take advantage of existing opportunities. The strategy that must be applied in this condition is to support an aggressive growth policy (Growth-oriented strategy).

b. Quadrant II. An organization faces various threats but still has internal strength. The strategy that must be applied is to use strength to take advantage of long-term opportunities by means of a diversification strategy.

c. Quadrant III. An organization gets a huge (external) opportunity, but on the other hand, it faces some internal constraints/weaknesses. The focus of this organization is to minimize the organization's internal problems so that it can seize opportunities from outside properly.

d. Quadrant IV. An organization is in an unfavorable situation, the organization faces various internal threats and weaknesses. The strategy used is to defend oneself to build internal strengths and minimize weaknesses.

From the results of the SWOT matrix calculation, the data compiled to determine the assessment can be arranged in a quadrant model as a means to determine the strategic steps to be chosen.

a. Value of internal Factor Analysis (IFA).

The value of IFA $=$ Strength $(\mathrm{S})-$ Weakness $(\mathrm{W})$

$=42.35-32.77$

$=9.58$

b. Value of External Factor Analysis (EFA).

The value of EFA = Opportunity $(\mathrm{O})-$ Threat $(\mathrm{T})$

$=31.65-29.90$

$=1.75$

From the calculation, it can be described in terms of the abscissa axis and the ordinate value of Internal Factor Analysis (IFA) of 9.58 and the value of External Factor Analysis (EFA) of 1.75. Based on the SWOT matrix model, strategic steps are in quadrant I (Aggressive), which means that increasing Navy's ship readiness in the Jakarta Military Sea Lift Unit has the power to be done to improve sea transportation capabilities. From the value of Internal Factor Analysis (IFA) and the value of External Factor Analysis (EFA) as much as can be described in the SWOT Matrix analysis quadrant model, Figure 1. 


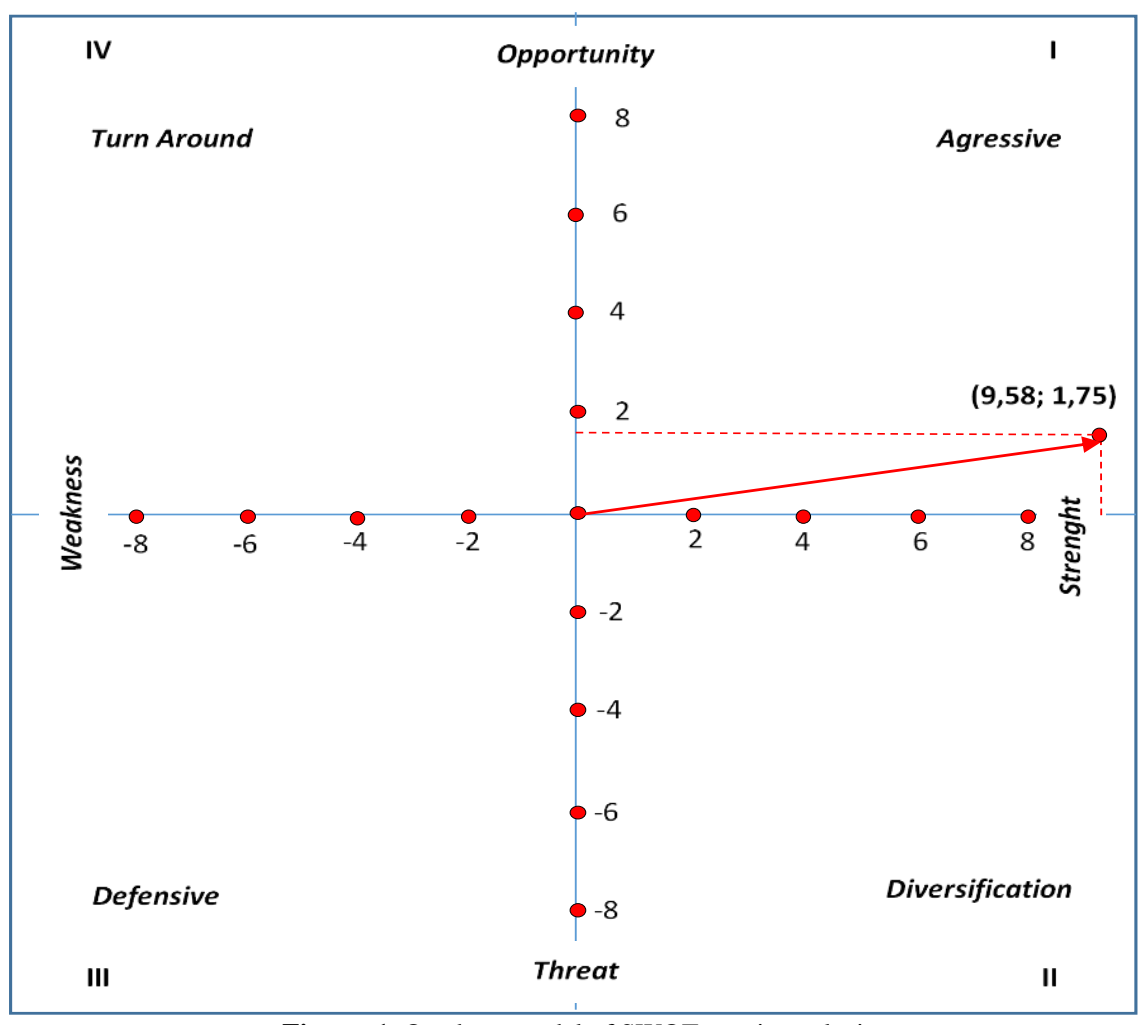

Figure. 1. Quadrant model of SWOT matrix analysis

The results of data processing can be analyzed for the best strategy based on a questionnaire assessment using SWOT analysis. From the results of data processing, it is known that of the 9 respondents who have given an assessment, all assessments meet the requirements. From the results of data processing through weight assessment and rating activities with strategic targets to support the improvement of Navy's ship readiness under of Jakarta Military Sea Lift Unit, the following strategies can be done:

\section{A. Strategy based on Strength-Weakness-Opportunity-} Threats (SWOT).

\section{Strength-Opportunity Strategy Collaboration}

This strategic collaboration is based on the strengths of the Indonesian Navy and the Military Sea Lift Command based on opportunities.

1. Develop planning for the Navy ship maintenance system by building cooperation with shipyards and weapons companies. Cooperation with shipyards affects the repair schedule, especially on the ship's hull. The implementation of ship repairs in shipyards needs to be prepared so that operational tasks are not disrupted.

2. Increasing the role of organizational responsibility for the maintenance of the Indonesian Navy Ship by building cooperation with Original Engine Manufacturers (OEM), on the machinery installed on the ship.

3. Improving Ship Maintenance Facility Unit readiness by utilizing 4.0 technology. Advances in technology 4.0 provide opportunities to be implemented in the

maintenance of Indonesian Navy ships, especially in monitoring and identifying the condition of ships in an integrated manner.

4. Build a reporting and maintenance system for Indonesian Navy ships by implementing 4.0 technology. The 4.0-based Navy ship maintenance reporting system will accelerate decision-making in an integrated manner.

5. Planning the maintenance of the Indonesian Navy Ships in accordance with the policy of Minimum Essential Force 2020-2024. The minimum essential force policy for 2020-2024 needs to be maximized to increase the capability of Navy ships to support the task of protecting national interests at sea.

6. Prepare the need for spare parts to support the Navy ship maintenance system in collaboration with supporting industries. Cooperation with supporting industries provides opportunities for the independence of components, equipment and prevents the occurrence of an embargo on component materials from foreign industries.

\section{Weakness-Opportunity Strategy Collaboration}

This strategic collaboration is based on the weakness of the Indonesian Navy and the Military Sea Lift Command based on opportunities.

1. Conducting a Tour of Duty for Indonesian Navy personnel to meet the Navy's ship Crew according to the list of personnel composition. Tour of Duty personnel activities provide the benefit of increasing experience and knowledge in supporting tasks

2. Doing training exercise at the Fleet Training Command Unit in collaboration with the original engine manufacturer (OEM) to improve the maintenance capabilities of the Indonesian Navy ships.

3. Cooperating with shipyards to improve the readiness 
of the Indonesian Navy ship platform. Cooperation with shipyards will increase the timeliness of ship maintenance on an annual basis to maintain the readiness of ship materials and equipment.

4. Cooperating with ship armament companies and implementing 4.0 technological advances to improve the Navy's ship Sewaco.

5. Establishing cooperation with PT Pertamina to support the fuel needs for Navy's ships at a minimum of 80 percent of the needs and cooperate with shipyards to build tankers to supply the fuel needs of Indonesian Navy ships.

6. Increasing the base's electrical power capacity to supply the ship's electrical power needs when docked to replenish and maintain ship's equipment. Sufficient electrical power capacity at Navy bases will provide opportunities for ships docked at base to repair equipment such as auxiliary engines and electrical sets.

7. Cooperating with Original engine manufacturers to improve the capabilities and skills of the personnel of Ship Maintenance Facility Unit to support ship repairs.

8. Recruiting local personnel to staff pf the Ship Maintenance Facility Unit. Recruitment of local personnel to manpower the Ship Maintenance Facility Unit facilitates coaching and prevents the change of this personnel on assignments to other places.

9. Planning and improving the capability of the Navy's ship maintenance facilities such as Ship Maintenance Facility Units. Modern maintenance facilities affect the speed and quality of ship maintenance so that the condition of the ship will be well maintained.

10. Procuring new equipment to support the maintenance of Indonesian Navy ships. Most of the ship maintenance equipment and infrastructure at the Ship Maintenance Facility Unit are more than 30 years old. This condition causes a decrease in the quality of ship maintenance. Thus, it is important to procure more modern equipment and infrastructure.

11. Preparing the availability of spare parts to support the Navy's ship maintenance system in a planned manner, both consumable spare parts and spare parts for ship repair.

12. Preparing a plan for the operation of the Indonesian Navy ships with a one-third operating model, onethird standby and one-third maintenance of machinery and equipment.

13. Developing a maintenance management system for Indonesian Navy ships by building a maintenance system with a planned maintenance system model and a spare part list book with the implementation of 4.0 technological advances.

14. Developing software and equipment needed for planned maintenance system by utilizing computerbased maintenance. preparation of software which includes facility master schedule sheets, work schedule boards and work cards on the Indonesian Navy ship as a tool to simplify the maintenance system. Preparation of facilities in the form of a schedule master sheet that is placed in the Naval Maintenance Unit as a step in monitoring maintenance activities on each navy Ship.

\section{Strength-Threat Strategy Collaboration}

This strategic collaboration is based on the strengths of the Indonesian Navy and the Military Sea Lift Command based on threat.

1. Building a spare parts supply system based on supporting industrial component products. Each component of the ship has a period of use. The provision of spare parts affects the performance of ship machinery to support ship operations. Based on information and data series for the condition of equipment, components, and machinery onboard, a repair plan and replacement of components with new spare parts can be drawn up.

2. Build cooperation with domestic industry to prepare Indonesian Navy personnel who have competence in the maintenance of Indonesian Navy ships. Cooperation with domestic supporting industries is useful in providing spare parts, components, ship equipment, making it easier to prepare ship conditions.

3. Developing policies for maintenance and development mechanisms to increase the number of Indonesian Navy ships in the 2020-2024 Minimum essential force program in collaboration with the domestic ship industry.

4. Building cooperation with the domestic original engine manufacturer industry to increase the content of local components to prevent spare parts embargoes.

\section{Weakness-Threat Strategy Collaboration}

This strategic collaboration is based on the weakness of the Indonesian Navy and the Military Sea Lift Command based on threats.

1. Improving the capability of the Ship Crew in technology and maintenance of the Indonesian Navy's ship equipment by training abroad during ship construction in shipyards.

2. Cooperating with overseas original engine manufacturers to support the need for spare parts during the Life Time period in the Platform and Sewaco fields. Cooperation training with OEM is carried out for ship crews who will have skills to repair and maintain machinery, equipment, and ship equipment.

3. Preparing Ship Maintenance Facility Unit personnel as the Base Maintenance Team for the maintenance and repair of the Indonesian Navy Ships. Cooperation training with original engine manufacturers is carried out for personnel at the Ship Maintenance Facility Unit. Personnel who have the skills can repair and maintenance of the ship.

4. Improving maintenance system management capabilities based on the Planned Maintenance System (PMS). 


\section{B. Strategy for improving the Navy's ship maintenance system.}

\section{Human resources skills}

The planned maintenance system requires software, so that the readiness of the Indonesian Navy ships can be carried out by the crew in accordance with technical specifications for the maintenance of all machinery. Increasing the knowledge of the ship crew through education and training and to improve the skills of the crew to be able to implement a planned maintenance system $[9,10]$.

To increase the ability of the Navy's ship Crew to be able to maintain equipment, it is necessary to train Crew Ships to support organic level maintenance. Training activities carried out by the fleet training command independently or in collaboration with Original Engine Manufacturers especially on specific equipment and components such as machinery, weapon system equipment and navigation radar equipment.

Personnel skills in the maintenance aspect are carried out through training for ship crew and personnel at Ship Maintenance Facility Unit. Improving the knowledge and skills of the Indonesian Navy's Ship Crew in implementing a planned maintenance system. Crew training to support platform and Sewaco preparation, especially in skills to support maintenance activities by ship crews.

Training activities for ship crew and ship maintenance facility unit personnel are carried out in an integrated manner with the original engine manufacturer installed on the ship.

\section{Planned maintenance system}

Supporting the planned maintenance system, various maintenance activities are carried out to prevent damage that could result in delays in operating activities [11]. Planned maintenance system to improve the maintenance of Indonesian Navy ships through increasing the skills of the Indonesian Navy ship crew on maintenance so that the ships are ready to support the shift of troops, materials and logistics.

The implementation of the planned maintenance system is carried out in order to improve the platform readiness of the Indonesian Navy ships with various aspects including: lubrication systems, fuel pumps, ship equipment, safety equipment, propulsion systems, weapons systems, navigation systems, communication systems and every component of the ship platform and Sewaco requires an intensive periodic inspection, maintenance or maintenance, in order to maintain optimum readiness of the Indonesian Navy Ship and to avoid damage when the ship is about to sail and is in a condition of sailing (readiness and sustainability).

Periodic inspection of the engine depends on the operating conditions, working hours of the engine, the quality of the lubricating oil, fuel and the way the engine operates [12]. Periodic inspection and maintenance are important so that the condition of the Indonesian Navy Ship is ready to operate to maintain the security and sovereignty of the State through troop shifts and logistics. Develop a maintenance management system for Indonesian Navy ships by building planned maintenance systems and a technology-based spare parts list.

\section{Availability of spare parts}

Availability of spare parts for maintenance at the organic level to achieve the readiness of Navy ships [13], in the operation and ships maintenance. Availability of spare parts to support vessel readiness during operation activities and availability of spare parts in vessel repair activities for medium maintenance and general overhaul maintenance.

Numbers of spare parts to support ship operations include various consumable spare parts such as fuel filters and packing materials to prevent fuel leakage, sea water cooling system and engine lubrication system. Strategies that need to be carried out to support the availability of spare parts include: identifying the need and availability of spare parts to support the planned maintenance system for Indonesian Navy's ships, preparing the need for Navy's ship spare parts to support planned based maintenance in collaboration with supporting industries, collaborating with the original engine manufacture (OEM) abroad [14], to support the need for spare parts during the Life period in the field of Indonesian Navy vessels Sewaco in the Jakarta Military Sea Lift Unit and build a spare parts supply system based on supporting industrial components to increase Sewaco's readiness.

\section{Ship Maintenance Facility Unit}

The condition and capability of the facilities and infrastructure at the Ship Maintenance Facility Unit have an influence on ship maintenance. Ship maintenance is carried out to prevent the occurrence of machining work failures. To prevent equipment failure and minimize possible loss of function, regular maintenance is required [15]. Preventive maintenance (PM) is carried out at predetermined intervals according to the specified criteria which is intended to reduce the possibility of failure and deterioration of machinery functions. Maintenance to increase capability, namely maintenance that is to increase operating capability and prolong lifetime [16, 17].

The readiness of the facilities and infrastructure of the Ship Maintenance Facility Unit can maintenance up to the depot level for all types of Indonesian Navy ships on both platforms and Sewaco aspects. Increasing the capability of ship maintenance unit facilities and infrastructure, especially ship docks, production equipment, machine workshop equipment, electronics workshop equipment and weapons workshop equipment will increase the Ship Maintenance Facility Unit's capability. At ship dock facilities, it is important to repair ship hull below the waterline [18].

\section{Implications of Navy's ship maintenance systems to support sea transportation}

Ship maintenance has an impact on the condition of the ship on the platform and Sewaco aspects. The role of the maintenance system on the readiness of ships to support sea transportation for shifting troops, materials, and logistics is shown in Figure 2. 


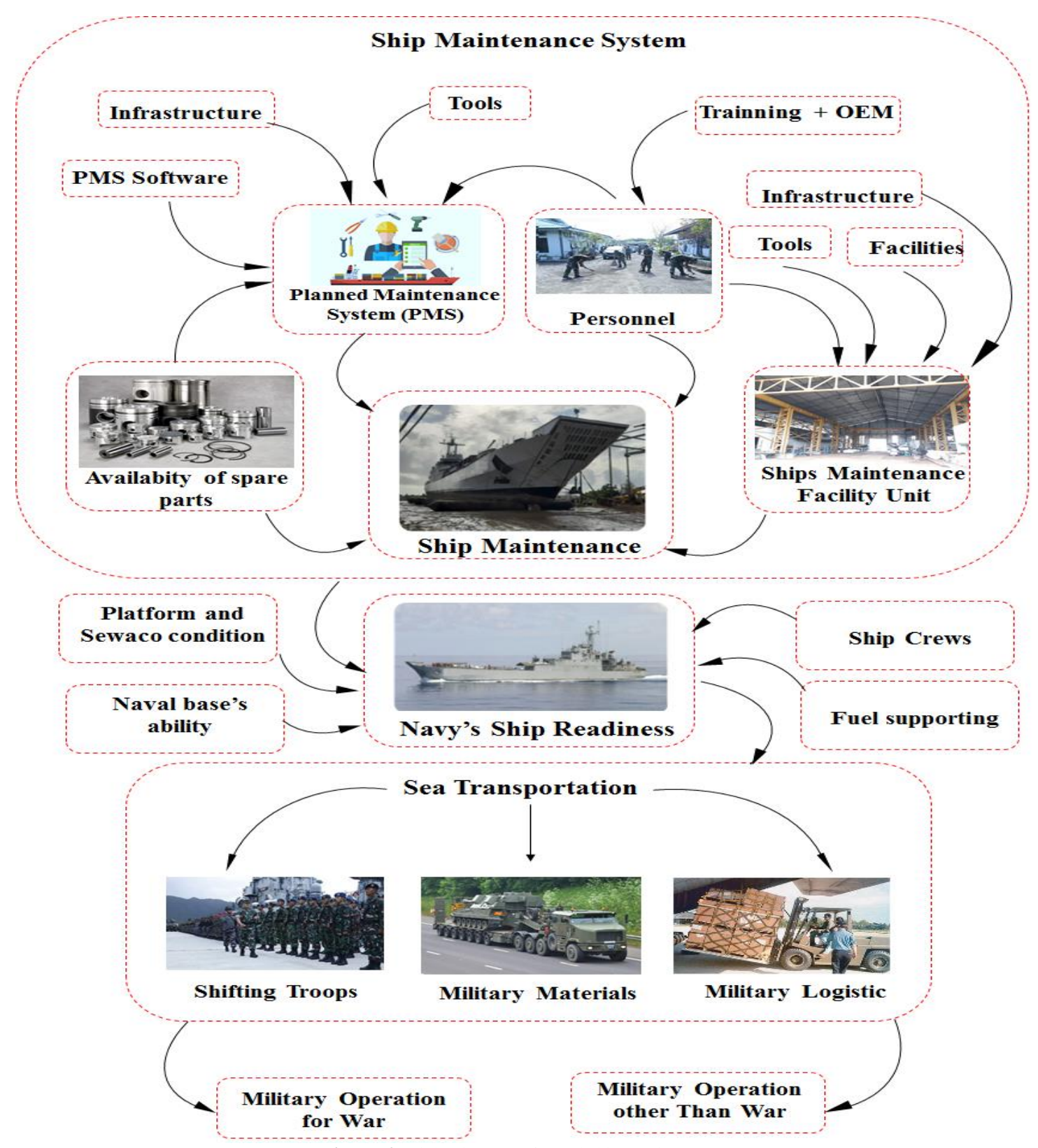

Figure. 2. Rich Diagram of naval ships maintenance

The readiness of the Indonesian Navy ships will have implications for the ability to maintain national interests at sea and state sovereignty. In the maritime aspect, the ability to maintain state sovereignty is influenced by the readiness of the ship. Ship readiness is influenced by the ability to maintain the Navy's ships readiness and sustainability. The readiness of the Indonesian Navy ships is determined by the crew's ability to maintain ships, fuel support, platform and rental conditions, the Navy's base capability and system maintenance.

Ship maintenance is based on the policy of maintaining the condition of the ship through maintenance based on the breakdown maintenance system and preventive maintenance system (PvM) [19]. The preventive maintenance system can be classified into a planned maintenance system (PMS) and a reliability maintenance system (RMS).

Personnel capabilities include ship crew and ship maintenance facility unit personnel. The ship's crew is intended to support organic-level maintenance. Organic level maintenance on board is carried out based on the machining component time period to maintain the condition of the equipment and machinery to operate, with the availability of On-Board Spare (OBS). The Ship Maintenance Facility Unit personnel are prepared to maintenance navy ships at the medium level and general overhaul level. Ship maintenance at the Ship Maintenance Facility Unit uses available equipment and facilities that are part of the Base Maintenance Team (BMT). The quality of maintenance by personnel will affect the readiness of the condition of the Navy ships [20]. To improve the capabilities and skills of personnel, training is carried out by educational institutions of the Indonesian Navy, the Training Fleet Command Unit and collaboration with the original engine manufacturer (OEM).

Maintenance management based on planned maintenance system is chosen to prevent failures in the operation of machinery and equipment [4]. Planned 
maintenance system is preventive maintenance (PvM) which is intended to prevent the occurrence of machine and equipment operation failures on board. The planned maintenance system onboard is carried out by the crew using consumable spare parts such as fuel filters and packing materials. The mid-level planned maintenance system is intended to maintain the technical condition of the platform, Sewaco and equipment carried out by the Ship Maintenance Facility Unit and shipyard, with spare parts provided by the Navy Material Supply Unit. At the general overhaul level maintenance is cumulative maintenance to restore to the initial condition of the platform, Sewaco and equipment on board. Platform maintenance is carried out to maintain the condition of the hull, ship machinery, tools and equipments. Sewaco maintenance is carried out to maintain the technical capabilities of anti-air warfare, anti-surface warfare, electronic warfare and naval gun fire support. To support the planned maintenance system, adequate facilities, infrastructure, equipment, software, skilled personnel and spare parts are needed [21].

Numbers of spare parts affect the readiness of Indonesian Navy ships, especially in the operation and maintenance process during docking repair. The availability of adequate spare parts has an influence on the readiness of machinery and tools on board [22]. The preparation of spare parts consists of two classifications, first, spare parts to support the daily maintenance of the ship which are consumable items and spare parts to support the ship maintenance system, both the medium maintenance level and the overhaul maintenance. Ship readiness requires the availability of onboard spares [13, $23,24]$, which include fuel filters for the main engine and auxiliary engine, and packing materials to prevent leakage of the fuel piping system, freshwater cooling and lubrication systems, in the amount of 80 percent of the needs. Spare parts for ship machinery maintenance to maintain ready-to-operate conditions need to be provided at 30 percent of the requirement. The availability of spare parts to support this planned maintenance system. The readiness of Navy ships operations is able to shift troops, materials and logistics to the operational area [25].

\section{IV.CONCLUSION}

In general, warships are prepared to operate for 30 years. To maintain the readiness of the Indonesian Navy ships, an adequate maintenance system is needed. The ship maintenance systems aspect is divided into two main categories, Preventive maintenance (PvM) and Corrective Maintenance (CM). PvM is further divided into Condition Based Maintenance (CBM) and Predetermined Maintenance (PM). Ships materials are operated until failure occurs and maintenance is carried out only after fault recognition. Ship maintenance to improve the readiness of the Indonesian Navy Ship at Jakarta Military Sea Lift Unit requires priority activities which include:

1. Preparation of software (software) to support the planned maintenance system at Navy ship.
2. Improving the knowledge and skills of the Indonesian Navy's Ship Crew to implement planned maintenance systems and organic level maintenance

3. Formulation of policies for increasing platform and rentco materials Preparation of adequate budget support by the needs to support platform and rentco readiness

4. Arranging of facilities for schedule master sheets, schedule work boards and job cards at Indonesian Navy ships as a means to facilitate the planned maintenance system.

5. Preparation of facilities in the form of schedule master sheets placed in the Naval Maintenance Unit as a monitoring step for maintenance activities on each Indonesian Navy Ship.

6. Increasing the availability of spare parts as needed to support the maintenance of Indonesian Navy ships

The readiness of the ship will increase the operational capability for shifting troops and logistics to the area of operation.

\section{ACKNOWLEDGMENTS}

Thanks to the Military Sea Lift Command officers, Operational Officer staff, Logistics officers staff and Navy ship Commanders at Jakarta Military Sea Lift Unit.

\section{REFERENCES}

[1] S. S. F. Regilme Jr, "Beyond paradigms: understanding the South China Sea dispute using analytic eclecticism," International Studies, vol. 55, pp. 213-237, 2018.

[2] P. Cai, "Understanding China's belt and road initiative," 2017.

[3] S. C. Moore, J. Stockfisch, M. S. Goldberg, S. M. Holroyd, and G. G. Hildebrandt, "Measuring military readiness and sustainability," RAND Corp Santa Monica CA1991.

[4] I. Alsyouf, "Measuring maintenance performance using a balanced scorecard approach," Journal of Quality in Maintenance Engineering, 2006.

[5] J. W. Creswell, Research design: Qualitative, quantitative, and mixed methods approaches: Sage publications, 2017.

[6] E. Akyuz and M. Celik, "Using of A'WOT to design an enhanced planned maintenance system (E-PMS) on-board ship," Brodogradnja: Teorija $i$ praksa brodogradnje $i$ pomorske tehnike, vol. 68, pp. 61-75, 2017.

[7] J. H. Witwicki, "The United States Navy as a Hollow Force-An Assessment of Naval Readiness from 2010 to 2017," Johns Hopkins University, 2020.

[8] T. Bradbury and C. Galloway, "SWOT analysis," in Encyclopedia of Sport Management, ed: Edward Elgar Publishing, 2021, pp. 480-482.

[9] A. M. Wahl and T. Kongsvik, "Crew resource management training in the maritime industry: a literature review," WMU Journal of Maritime Affairs, vol. 17, pp. 377-396, 2018.

[10] J. Freeman and W. Zachary, "Intelligent tutoring for team training: Lessons learned from US military research," in Building Intelligent Tutoring Systems for Teams, ed: Emerald Publishing Limited, 2018.

[11] I. Lazakis, Y. Raptodimos, and T. Varelas, "Predicting ship machinery system condition through analytical reliability tools and artificial neural networks," Ocean Engineering, vol. 152, pp. 404-415, 2018.

[12] M. Łutowicz, "Impact of the Engine Tuning on its Technical Condition Assessment Based on Limited Number of Available Parameters," New Trends in Production Engineering, vol. 1, pp. 721-728, 2018.

[13] W. C. H. Needs, "Report to Congress," Washington, DC: US Department, 2011. 
[14] R. G. Keane, B. F. Tibbitts, and P. E. Jaquith, "The Navy's Ship Design Factory: NAVSEA-The "Golden Goose"," Naval Engineers Journal, vol. 131, pp. 61-78, 2019.

[15] J. Cullum, J. Binns, M. Lonsdale, R. Abbassi, and V. Garaniya, "Risk-Based Maintenance Scheduling with application to naval vessels and ships," Ocean Engineering, vol. 148, pp. 476-485, 2018.

[16] M. Rausand and A. Hoyland, System reliability theory: models, statistical methods, and applications vol. 396: John Wiley \& Sons, 2003.

[17] C. Scheffer and P. Girdhar, Practical machinery vibration analysis and predictive maintenance: Elsevier, 2004

[18] I. Atanasova, T. Damyanliev, P. Georgiev, and Y. Garbatov, "Analysis of SME ship repair yard capacity in building new ships," in Progress in Maritime Technology and Engineering, ed: CRC Press, 2018, pp. 431-438.

[19] I. Lorencin, N. Anđelić, V. Mrzljak, and Z. Car, "Multilayer perceptron approach to condition-based maintenance of marine CODLAG propulsion system components," Pomorstvo, vol. 33, pp. 181-190, 2019.

[20] X. Biao, "The Warship Equipment Life Cycle Design Based on the Supportability System Engineering for the People's Armed Police Coast Guard," in IOP Conference Series: Materials Science and Engineering, 2021, p. 022058.

[21] L. Casadiego, E. A. B. Blandos, E. G. P. Sanabria, M. R. Pianeta, J. S. P. Ramírez, and N. F. Z. Portillo, "Analysis of integrated logistics support (ILS) in the shipbuilding industry. Advantages and improvement opportunities for the naval industry. COTECMAR case study," Ship Science and Technology, vol. 14, pp. 9-17, 2021.

[22] C. Kandemir and M. Celik, "A human reliability assessment of marine auxiliary machinery maintenance operations under ship PMS and maintenance 4.0 concepts," Cognition, Technology \& Work, pp. 1-15, 2019.

[23] M. I. Axinto and M. S. Giles, "Review and analysis of selected items management (SIM) inventory program aboard US surface ships," Naval Postgraduate School Monterey CA2005.

[24] B. Martin, R. J. Yardley, P. Pardue, B. Tannehill, E. Westerman, and J. Duke, "An Approach to Lifecycle Management of Shipboard Equipment," 2018.

[25] G. Heaslip and E. Barber, "Using the military in disaster relief: systemising challenges and opportunities," Journal of Humanitarian Logistics and Supply Chain Management, 2014. 